\title{
Action of benzalkonium chloride in different $\mathrm{pH}$
}

\author{
Rogério Frozza1,* (1) https://orcid.org/0000-0003-4856-5193 \\ Cesar Bado² (D) https://orcid.org/0000-0003-1130-9428 \\ João Eduardo Schneider² (D) https://orcid.org/0000-0001-8405-7781 \\ Ana Caselles ${ }^{3}$ (D) https://orcid.org/0000-0003-2976-6117 \\ Pedro Henrique Filsner² (D) https://orcid.org/0000-0002-7979-096X \\ Juliana Sperotto Brum¹ (D) https://orcid.org/0000-0003-2147-9439 \\ 1. Universidade Federal do Paraná - Programa de Pós-Graduação em Ciências Veterinárias - Setor de Ciências Agrárias - \\ Curitiba (PR), Brazil. \\ 2. Sanphar Saúde Animal - Departamento Técnico de Suinocultura - Campinas (SP), Brazil. \\ 3. Sanphar Saúde Animal - Departamento Técnico de Avicultura - Campinas (SP), Brazil. \\ *Corresponding author: frozza.rogerio@gmail.com
}

\section{ABSTRACT}

Ammonium quaternary compounds are widely used in poultry and swine production as disinfectants in the control of pathogens. They act on gram-positive bacteria, gram-negative bacteria, enveloped fungi and viruses. However, in some conditions of $\mathrm{pH}$ and presence of organic matter can be inactivated. This study evaluated the action of ammonium quaternary compounds at 1:1,000 and 1:2,000 dilutions against Salmonella enterica serovarTyphimurium and Salmonella enterica serovar Enteritidis in the presence of three different organic matter simulators, fetal bovine serum, skim milk and whole milk concentration of $1,3,5$, and $7 \%$ and at $\mathrm{pH} 6$ and 9 , with 15 min of contact. It was possible to verify that the organic matter simulators adjusted in the same conditions of contact time and percentage, in the in vitro tests, presented different results and the fetal bovine serum did not inactivate the disinfectant. However, the best result against S. Typhimurium and S. Enteritidis was obtained at pH 6 at the dilution of 1:1,000 in all organic matter simulators.

Keywords: biosecurity; quaternary ammonium;organic matter; Salmonella.

Quaternary ammonium compounds (QAC) are the main cationic surfactants, widely used as disinfectants and detergents since the late 1930s in different environments,such asdomestic, industrial,agricultural and clinical facilities (TEZEL; PAVLOSTATHIS, 2011; ZHANG et al., 2015). These compoundsplayan important role when used in breeding and management systemslikefarms, barns and even hatcheries by reducing the pathogen load,therefore keeping a health standard (GERBA, 2015; PAULINO, 2002).

Quaternary ammonium compounds are organic compounds with two well-defined regions in their molecular structures, one of those having four different functional groups bound to a central nitrogen atom, named cationic region (positively charged),the othercalled anionic region (negativelycharged) where usually chlorine $\left(\mathrm{Cl}^{-}\right)$or bromine $(\mathrm{Br}$ ) binds to nitrogen (AL-ADHAM et al., 2013; GERBA, 2015; MCDONNELL, 2007).

For high antimicrobial activity, it is the requirement for QAC, that nitrogen is connected to an alkyl chain between C8 and C18, been C12 to C16 the groups with higher biocidal activity. (AL-ADHAM et al., 2013; GERBA, 2015; GORMAN; MARIS, 1995; SCOTT, 2004). The wide varietyof QAC chemical structures allowed the evolution to a more efficient antimicrobial activity, reduced the toxicity of the compounds and the development of new generation of products (AL-ADHAM et al., 2013; GERBA, 2015).

Acting over gram-negative and gram-positive bacteria, fungi and enveloped virus (CFSPH, 2008; KUANA, 2009; PAULINO, 2002; RUTALA; WEBER, 2001). According to GERBA (2015), QACcan interact with specific intracellular targets and bind with DNA, in some formulations the ability to inactivate nonenveloped virus is reported. For the optimum efficiency, the $\mathrm{pH}$ must range from neutral to slightly alkaline (AL-ADHAM et al., 2013; GORMAN; SCOTT, 2004; GREZZI, 2008; MORGULIS; SPINOSA, 2005; PAULINO, 2002; SESTI, 2005).

Received: Sep 24, 2018. Accepted: Oct 22, 2021

Associate Editor: Silvia Galleti

Peer Review History: Double-blind Peer Review. 
Taking this information into account, a benzalkonium chloride-basedbiocide was tested in two different dosages, 1:1,000 and 1:2000, with several concentrations of organic matter (OM) ranging from 1,3,5, and 7\%, for whole milk (WM), skim milk (SM) and bovine fetal serum (BFS), in solutions with distinct pH levels 6 and 9. The organisms employed on the test, Salmonella enteric serovar Typhimurium and S.enteric serovar Enteritidis, were obtained from field samples, stored at the Centro de Diagnóstico de Sanidade Animal (CEDISA) collection, Concórdia, Santa Catarina, Brazil.The methodology applied was adapted from DIN EN 1276 (GRESSNER, A.; GRESSNER, O., 2019).

The strains were incubated in nutrient agar at $37^{\circ} \mathrm{C}$ for 18 to $24 \mathrm{~h}$ under aerobic conditions. Later, the culture was diluted in saline solution and the inoculum standardized to contain 108 colony forming units (CFU) $\mathrm{mL}^{-1}$. The substances used to mimic OM WM and SM, as mentioned previously, were diluted in the following concentrations 1, 3, 5, and 7\%, in $1 \mathrm{~mL}$.

After standardization, $1 \mathrm{~mL}$ of inoculum was added to the test tube, followed by the addition of $1 \mathrm{~mL}$ of OM, also adjusted, in concentrations of $1,3,5$, and $7 \%$ of WM and SM. Subsequently, $8 \mathrm{~mL}$ of disinfectant solution was added to the tubes at dilutions of $1: 1,000$ and $1: 2,000$.

In 1-mL inoculum, $1,3,5$, and $7 \%$ bovine fetal serum (BFS) were added to test tubes, afterward this solution was transferred to an $8 \mathrm{~mL}$ of standardized inoculum and was added in a test tube. Then, $1 \mathrm{~mL}$ of BFSin concentration 1, 3, 5, and 7\% was added in $8 \mathrm{~mL}$ of disinfectant solution in dilutions of 1:1,000 and 1:2,000.

The tubes were homogenized and kept at room temperature for $15 \mathrm{~min}$. Then an aliquot of $1 \mathrm{~mL}$ of the solution was transferred to a tube containing $8 \mathrm{~mL}$ of nutrient broth with $0.5 \%$ tween 80 and $0.07 \%$ lecithin (Letheen broth), then added $1 \mathrm{~mL}$ of distilled water, properly homogenized and rested for $5 \mathrm{~min}$.

In the sequence, $1 \mathrm{~mL}$ of the solution was added in a tube containing $9 \mathrm{~mL}$ of phosphate buffered saline (PBS) at $\mathrm{pH}$ 7.4. Of this solution, $100 \mu \mathrm{L}$ were seeded in triptych soy agar (TSA) plates and incubated for 18 to $24 \mathrm{~h}$ at a temperature of $36 \pm 1{ }^{\circ} \mathrm{C}$. The efficiency of the disinfectant was expressed in log reduction, being considered the reduction of four logs (99.99\%) between the initial population and the surviving population. The procedure was performed at $\mathrm{pH} 6$ and 9.

The disinfectant was efficient when tested for inhibition of SE in the dilutions of 1:1,000 at pH 6 in the presence of OM (BFS, WM and SM) in concentrations of 1, 3, 5, and 7\%, as can be observed in Table 1. At pH 9, respecting the same dilution of product, OM and their respective percentages, the disinfectant was not effective against SE in WM at 7\%.

Table 1. Quaternary ammonium based disinfectant activity against Salmonella Enteritidis in two different dilutions, pH6 and 9 and with different concentrations of different organic matter, after 15 min of contact.

\begin{tabular}{|c|c|c|c|c|}
\hline & \multicolumn{2}{|c|}{$1: 2,000$} & \multicolumn{2}{|c|}{$1: 1,000$} \\
\hline & $\mathrm{pH} 6$ & pH9 & pH6 & pH9 \\
\hline BFS $1 \%$ & $\mathrm{~S}$ & $\mathrm{~S}$ & $\mathrm{~S}$ & $\mathrm{~S}$ \\
\hline BFS 3\% & $\mathrm{S}$ & $\mathrm{S}$ & $\mathrm{S}$ & $S$ \\
\hline BFS 5\% & $\mathrm{S}$ & $S$ & $\mathrm{~S}$ & $\mathrm{~S}$ \\
\hline BFS 7\% & $\mathrm{S}$ & $\mathrm{S}$ & $\mathrm{S}$ & $\mathrm{S}$ \\
\hline WM 1\% & $\mathrm{S}$ & $\mathrm{S}$ & $\mathrm{S}$ & $\mathrm{S}$ \\
\hline WM 3\% & $\mathrm{S}$ & $\mathrm{S}$ & $\mathrm{S}$ & $\mathrm{S}$ \\
\hline WM 5\% & $\mathrm{R}$ & $\mathrm{R}$ & $\mathrm{S}$ & $\mathrm{S}$ \\
\hline WM 7\% & $\mathrm{R}$ & $\mathrm{R}$ & $\mathrm{S}$ & $\mathrm{R}$ \\
\hline SM 1\% & $\mathrm{S}$ & $\mathrm{S}$ & $\mathrm{S}$ & $\mathrm{S}$ \\
\hline SM 3\% & $\mathrm{S}$ & $\mathrm{S}$ & $\mathrm{S}$ & $\mathrm{S}$ \\
\hline SM 5\% & $\mathrm{S}$ & $\mathrm{R}$ & $\mathrm{S}$ & $S$ \\
\hline SM 7\% & $\mathrm{S}$ & $\mathrm{R}$ & $\mathrm{S}$ & $\mathrm{S}$ \\
\hline
\end{tabular}

BFS: bovine fetal serum; WM: whole milk; SM: skimmed milk. Sensitive(S): Inoculum that presented a logarithmic reduction of four logs (99.99\%). Resistant (R): Inoculum that did not present a logarithmic reduction of four logs (99.99\%).

Source: Elaborated by the authors.

At 1:2,000 dilution, the disinfectant inactivated SE at BFS 1,3,5 and 7\% at pH6 and 9. In the same dilution of the product and in WM, both at pH6 and 9, there was a reduction of growth in the concentrations of 1 and $3 \%$ and was not effective in the concentrations 5 and 7\%. However, in pH6 in concentrations of SM 1, 3, 5, and 7\% there was no growth. When compared to pH9 there was growth in SM in concentrations of 5 and 7\%, as described in Table 2.

When challenged against ST, the disinfectant was efficient in the dilutions of 1:1,000 and 1:2,000 at pH6 and 9 for BFS $1,3,5$ and $7 \%$. In the dilution of 1:1,000 at $\mathrm{pH} 6$ there was a bacterial reduction of $99.99 \%$ at WM 1, 3, and 5\%.At pH9, the disinfectant was efficient only at WM 1 and 3\%. In the same concentrations of WM, in the dilution of 1:1,000 the disinfectant was efficient only at $1 \%$, both at $\mathrm{pH} 6$ and 9 . 
Table 2.Disinfectant based on ammonium quaternary against Salmonella Typhimurium in two different dilutions, pH6 and 9 and with different concentrations of different organic matter, after 15 min of contact in different dilutions.

\begin{tabular}{|c|c|c|c|c|}
\hline & \multicolumn{2}{|c|}{$1: 2,000$} & \multicolumn{2}{|c|}{$1: 1,000$} \\
\hline & pH6 & pH9 & pH6 & pH9 \\
\hline BFS 1\% & $\mathrm{S}$ & $\mathrm{S}$ & $\mathrm{S}$ & $S$ \\
\hline BFS 3\% & $\mathrm{S}$ & $\mathrm{S}$ & $\mathrm{S}$ & $S$ \\
\hline BFS 5\% & $\mathrm{S}$ & $\mathrm{S}$ & $\mathrm{S}$ & $\mathrm{S}$ \\
\hline BFS 7\% & $\mathrm{S}$ & $\mathrm{S}$ & $\mathrm{S}$ & $S$ \\
\hline WM 1\% & $\mathrm{S}$ & $\mathrm{S}$ & $\mathrm{S}$ & $\mathrm{S}$ \\
\hline WM 3\% & $\mathbf{R}$ & $\mathbf{R}$ & $S$ & $S$ \\
\hline WM 5\% & $\mathbf{R}$ & $\mathbf{R}$ & $\mathrm{S}$ & $\mathbf{R}$ \\
\hline WM 7\% & $\mathbf{R}$ & $\mathbf{R}$ & $\mathbf{R}$ & $\mathbf{R}$ \\
\hline SM 1\% & $S$ & $\mathrm{~S}$ & $S$ & $S$ \\
\hline SM 3\% & $\mathrm{S}$ & $\mathbf{R}$ & $\mathrm{S}$ & $S$ \\
\hline SM 5\% & $\mathbf{R}$ & $\mathbf{R}$ & $\mathbf{R}$ & $\mathbf{R}$ \\
\hline SM 7\% & $\mathbf{R}$ & $\mathbf{R}$ & $\mathbf{R}$ & $\mathbf{R}$ \\
\hline
\end{tabular}

BFS: bovine fetal serum; WM: whole milk; SM: skimmed milk. Sensitive(S): inoculum that presented a logarithmic reduction of four logs (99.99\%). Resistant (R): inoculum that did not present a logarithmic reduction of four logs (99.99\%).

Source: Elaborated by the authors.

In SM, the disinfectant was efficient in the dilution of 1:1,000 in concentrations of 1 and $3 \%$ at pH6 and 9 . At the dilution of 1:2,000, the disinfectant was efficient in concentrations of SM 1 and 3\% at pH6 and only in concentrations of $1 \%$ at $\mathrm{pH} 9$, according to Table 2 .

According to WALIA et al. (2017), the main mechanism of action of benzalkonium chloride is the rupture of the lipid layer of the cytoplasmic membrane followed by extracting cytoplasmic components and eventual cell lysis. The following sequence of events was suggested to microorganisms exposed to cationic agents (CARMONA-RIBEIRO; CARRASCO, 2013; GERBA, 2015; MCDONNELL, 2007): 1) adsorption and penetration of the agent to the cell wall; 2) reaction with the cytoplasmic membrane, followed by membrane disorganization; 3) leakage of low molecular weight material; 4) degradation of proteins and nucleic acids; and 5) cell wall lysis caused by autolytic enzymes.

However, several studies show that factors inherent to product chemistry, field application conditions and target microorganisms can compromise the effectiveness of disinfectants and therefore should be tested (DAVIES, 2003; DVORAK, 2008; GREZZI, 2008; MAILLARD, 2013; RUTALA; WEBER, 2001; TAMÁSI, 1995).

This study has found that the activity of the disinfectant is inversely proportional to the concentration of OM, i.e., by increasing the concentration of $\mathrm{OM}$, the disinfectant becomes incapable of inactivating the microorganisms, except with BFS, where the disinfectant was efficient in all treatments. According to MAILLARD (2013), OM compromises the action of disinfectants in three ways: 1) reduction of the available concentration of the disinfectant; 2) protection of microorganisms from external damage; and 3) formation of microbial aggregates wrapped per layer of exopolysaccharides.

The BFS used as an OM simulator in the assay is usually produced from blood extracted from a bovine fetus from pregnant cows sent to slaughter and is universally used as an "additive" for cell culture (HEMEDA et al., 2014). Although widely used and with a worldwide consumption demand of around 500,000 L/year, they present quantitative and qualitative variations in their flocks (GSTRAUNTHALER, 2003). According to Table 3, only 4.07\% of the organic components of BFS are effectively capable of inactivating the disinfectants, that is, in the condition of $7 \%$ challenge OM with BFS, $0.28 \%$ of substances are able to inhibit the activity of the disinfectant.

Table 3. Components of bovine fetal serum and their variation according to the certificate and analysis of the supplier.

\begin{tabular}{lcc}
\hline Components & Specification & Concentration \\
\hline Total protein & $3.50-5.50 \mathrm{~g} / 100 \mathrm{~mL}$ & $4.07 \mathrm{~g} / 100 \mathrm{~mL}$ \\
\hline Hemoglobin & $0.001-0.03 \mathrm{~g} / 100 \mathrm{~mL}$ & $0.01779 \mathrm{~g} / 100 \mathrm{~mL}$ \\
\hline Bacteria & Negative & Negative \\
\hline Fungi & Negative & Negative \\
\hline Mycoplasma & Negative & Negative \\
\hline
\end{tabular}

Source: Adapted from Bovine Fetal Serum Analysis Certificate provided by the supplier. 
Milk, also used as an OM simulator, consists of approximately $87 \%$ water and the remaining 12 to $13 \%$ solid elements. The main solid elements of milk are lipids, carbohydrates, proteins, mineral salts and vitamins. Thus, total milk solids (TS) include all components except water. However, non-fat milk solids (NFMS) are all elements of milk except water and fat (BRITO et al., 2007). For Decree 9.013 of March 29, 2017 (BRAZIL, 2017), milk is considered to meet the specifications of Table 4.

Table 4. Composition and physical-chemical characteristics of milk.

\begin{tabular}{lcc}
\hline \multirow{2}{*}{ Components } & \multicolumn{2}{c}{ Requirements } \\
\cline { 2 - 3 } & WM & SM \\
\hline Fat $(\mathrm{g} / 100 \mathrm{~g})$ & Minimum 3.0 & Maximum 0.5 \\
\hline Non-greasy solids $(\mathrm{g} / 100 \mathrm{~g})$ & Minimum 8.4 & Minimum 8.4 \\
\hline Total solids $(\mathrm{g} / 100 \mathrm{~g})$ & Minimum 11.4 & Minimum 8.9 \\
\hline
\end{tabular}

WM: whole milk; SM: skimmed milk.

Source: Adapted fromBRAZIL(2017).

Taking into account the milk constituents capable of inactivating the activity of disinfectants, for the WM is $11.4 \%$, or $7 \%$ of WM, only $0.798 \%$ compromises the action of the disinfectant and for the SM at $7 \%$, only $0.623 \%$ inhibits the action of the disinfectant.

In relation to $\mathrm{pH}$, it is necessary to resume the initial stage of the mechanism of action, that is, the adsorption and penetration of the disinfectant the bacterium depend on the electrostatic interaction between the cationic portion of the QAC molecule with the negatively charged proteins in the bacterial cell membrane, and then they pierce the bacterial lipid layer, causing the rupture of the membrane and leakage of cell content and cell lysis (JENNINGS et al., 2016; MELIN et al., 2016).

MAILLARD (2013) states that the change in $\mathrm{pH}$ can also alter the load on the cell surface, i.e., as the $\mathrm{pH}$ increases, the number of negatively charged groups on the bacterial surface would also increase, improving the degree of bonding with cation, thus improving the action of the disinfectant. This statement corroborates with other authors who state that the optimal pH of performance for QAC is alkaline (AL-ADHAM et al., 2013; GORMAN; SCOTT, 2004; GREZZI, 2008; MORGULIS; SPINOSA, 2005; PAULINO, 2002; SESTI, 2005).

Given the results of the study, it is possible to conclude that the disinfectant showed better results under study conditions at slightly acidic $\mathrm{pH}$. The WM and SM compromised the action of the disinfectant studied and can be used as alternatives in substitution of the BFS to simulate the effect of the OM. Regarding the BFS, it did not compromise the action of the disinfectant in any assay of the study and, for this reason, it is not the most suitable simulator of OM for studies of the effectiveness of disinfectants.

\footnotetext{
AUTHORS' CONTRIBUTIONS

Conceptualization: Frozza, R.; Brum, J.S. Data curation: Frozza, R.; Brum, J.S. Formal analysis: Frozza, R.; Brum, J.S.; Filsner, P.H. Funding acquisition: Frozza, R.; Brum, J.S. Investigation: Frozza, R.; Brum, J.S.; Caselles, A.; Methodology: Frozza, R.; Brum, J.S.; Schneider, J.E.; Bado, C. Project administration: Frozza, R.; Brum, J.S. Supervision: Frozza, R. Brum, J.S. Visualization: Frozza, R.; Brum, J.S.; Schneider, J.E.; Bado, C.; Caselles, A. Writing - original draft: Frozza, R.; Filsner, P.H. Writing - review \& editing: Frozza, R.; Filsner, P.H.; Brum, J.S.
}

AVAILABILITY OF DATA AND MATERIAL

The datasets generated and/or analyzed during the current study are available in the Acervo Digital UFPR, persistent web link to datasets, https://acervodigital.ufpr.br/handle/1884/56198.

\section{FUNDING}

This work did not receive any specific grant from funding agencies in the public, commercial, or not-for-profit sectors.

\section{CONFLICTS OF INTEREST}

The authors certify that they have no commercial or associative interest that represents a conflict of interest in connection with the manuscript.

\section{ETHICAL APPROVAL}

Not applicable.

\section{ACKNOWLEDGEMENTS}

Not applicable. 


\section{REFERENCES}

Al-ADHAM, I.; HADDADIN, R.; COLLIER, P. Types of Microbicidal and Microbistatic Agents. In: FRAISE, A.P.; MAILLARD, J.-Y.; SATTAR, S.A. (ed). Russell, Hugo \& Ayliffes: Principles and Practice of Disinfection, Preservation and Sterilization. 5th. Ed. Iowa: Wiley Blackwell, 2013. chap.2, p.5-70. https://doi.org/10.1002/9781118425831.ch2

BRITO, M.A.; BRITO, J.R.; ARCURI, A.; LANGE, C.; SILVA, M.; SOUZA, G. Agronegócio do Leite. Brasília: Embrapa, 2007.Available from: http://www.agencia.cnptia.embrapa.br/Agencia8/AG01/arvore/AG01_128_21720039243.html. Access on: 12 Dez. 2017.

BRAZIL. Decreto $n^{\circ}$ 9.013, de 29 de março de 2017. Regulamenta a Lei ${ }^{\circ} 1.283$, de 18 de dezembro de 1950, e a Lei $n^{\circ} 7.889$, de 23 de novembro de 1989, que dispõem sobre a inspeção industrial e sanitária de produtos de origem animal. Diário Oficial da União: Brasília, 2017.Available from: https://www.in.gov.br/materia/-/asset_publisher/Kujrw0TZC2Mb/content/id/20134722/do1-2017-03-30-decreton-9-013-de-29-de-marco-de-2017-20134698. Access on: 10 Aug. 2017.

CARMONA-RIBEIRO, A.M.; CARRASCO, L.D.M.Cationic Antimicrobial Polymers and Their Assemblies. International Journal of Molecular Sciences, v.14, n.5, p.9906-9946, 2013. https://doi.org/10.3390/ijms14059906

CFSPH - The Center for Food Security and Public Health Iowa. Characteristics of Selected Disinfectants. Lakewood: American Animal Hospital Association, 2008. Available from: https://www.cfsph.iastate.edu/Disinfection/Assets/CharacteristicsSelectedDisinfectants.pdf. Access on: 10Aug. 2017.

DAVIES, D. Understanding biofilm resistance to antibacterial agents. Nature Reviews Drug Discovery, London, v.2, n.2, p.114-122, 2003. https://doi.org/10.1038/nrd1008

DVORAK, G. Disinfection 101. Ames: Center for Food Security and Public Health, 2008.Available from: https://www.cfsph.iastate.edu/ Disinfection/Assets/Disinfection101.pdf. Access on: 11Nov. 2021.

GERBA, C.P. Quaternary Ammonium Biocides: Efficacy in Application. Applied and Environmental Microbiology, East Lansing, v.81, n.2, p.464-469, 2015. https://doi.org/10.1128/AEM.02633-14

GORMAN, S.; SCOTT, E. Chemical Disinfectants, Antiseptics and Preservatives. In: DENYER, S.P.; HODGES, N.A.; GORMAN, S.P. (ed). Hugo and Russell's Pharmaceutical Microbiology. 7th.Ed. Massachusetts: Blackwell Science, 2004.chap.17, p.285-305. https://doi. org/10.1002/9780470988329.ch17

GRESSNER, A.M.; GRESSNER, O.A. Deutsches Institut für Normung e.V. (DIN). In: GRESSNER, A.M.; ARNDT, T. (eds.). Lexikon der Medizinischen Laboratoriumsdiagnostik. Berlin: Springer, 2019. 686p. https://doi.org/10.1007/978-3-662-48986-4_869

GREZZI, G. Limpeza e desinfecção na avicultura. Engormix, 2008.Available from: http://pt.engormix.com/avicultura/artigos/limpezadesinfeccao-avicultura-t36727.htm. Access on: 10 Aug. 2017.

GSTRAUNTHALER, G. Alternatives to the use of fetal bovine serum: serum-free cell culture. ALTEX, Heidelberg, v.20, n.4, p.275-281, 2003. Available from: https://pubmed.ncbi.nlm.nih.gov/14671707/. Access on: 10 Aug. 2017.

HEMEDA, H.; GIEBEL, B.; WAGNER, W. Evaluation of human platelet lysate versus fetal bovine serum for culture of mesenchymal stromal cells. Cytotherapy, Philadelphia, v.16, n.2, p.170-180, 2014. https://doi.org/10.1016/j.jcyt.2013.11.004

JENNINGS, M.C.; MINBIOLE, K.P.C.; WUEST, W.M. Quaternary Ammonium Compounds: An Antimicrobial Mainstay and Platform for Innovation to Address Bacterial Resistance.ACS Infectious Diseases, Minnesota, v.1, n.7, p.288-303, 2016. https://doi.org/10.1021/ acsinfecdis.5b00047

KUANA, S.L. Limpeza e desinfecção de instalações avícolas. In: BERCHIERI JÚNIOR, A.; SILVA, E.N.; DI FABIO, J.; SESTI, L. (eds). Doenças das aves. 2nd.Ed. Campinas: FACTA, 2009.chap.1.2, p.21-38.

MAILLARD, J.-Y. Factores affecting the activities microbicides. In: FRAISE, A.P.; MAILLARD, J.-Y.; SATTAR, S.(eds.).Russell, Hugo and Ayliffe's: Principles and Practice of Disinfection, Preservation and Sterilization. 5th.ed. Iowa: Wiley Blackwell, 2013.chap.3, p.71-86. 
MARIS, P. Modes of action of disinfectants. Revue scientifique et technique (International Office of Epizootics), France, v.14, n.1, p.47-55, 1995. https://doi.org/10.20506/rst.14.1.829

MCDONNELL, G. Biocides: Modes of action and mechanisms of resistance. In: MANIVANNAN, G. Disinfection and decontamination: Principles, applications and related issues. NewYork: CRC, 2007. chap.6, p.88-120.

MELIN, V.E.; MELIN, T.E.; DESSIFY, B.J.; NGUYEN, C.T.; SHEA, C.S.; HRUBEC, T.C. Quaternary ammonium disinfectants cause subfertility in mice by targeting both male and female reproductive processes. Reproductive Toxicology, Ispra, v.59, p.159-166, 2016. https://doi.org/10.1016/j.reprotox.2015.10.006

MORGULIS, M.S.F.A.; SPINOSA, H.S. Antimicrobianos: Desinfetantes. In: PALERMO-NETO, J.; SPINOZA, H.S.; GORNIAK, S.L. Farmacologia aplicada à avicultura. São Paulo:Rocca, 2005.chap.7, p.105-114.

PAULINO, C.A. Anti-sépticos e desinfetantes. In: SPINOZA, H.S.; GORNIAK, S.L.; BERNASI, M.M. Farmacologia aplicada à Medicina Veterinária. 2nd.Ed. Rio de Janeiro: Guanabara Koogan, 2002. chap.35, p.386-397.

RUTALA, W.A.; WEBER, D.J. Draft Guideline for Disinfection and Sterilization in Healthcare Facilities. Atlanta:Centers for Disease Control and Prevention, 2001. Available from: http://hica.jp/cdcguideline/dsguide.pdf. Access on: 13 Aug. 2017.

SESTI, L.A.C. Biosseguridade em granjas de reprodutoras. In: MACARI, M.; MENDES, A.A. Manejo de matrizes de corte. 2.ed. Campinas: Facta, 2005.chap.12, p.244-321.

TAMÁSI, G. Testing disinfectants for efficacy. Revue scientifique et technique (International Office of Epizootics), France, v.14, n.1, p.75-79, 1995. https://doi.org/10.20506/rst.14.1.827

TEZEL, U.; PAVLOSTATHIS, S.G. Role of Quaternary Ammonium Compounds on Antimicrobial Resistance in the Environment. In: KEEN, P.L.; MONTFORTS, M.H.M.M. (ed). Antimicrobial Resistance in the Environment. Hoboken: John Wiley \& Sons, 2011. chap.20, p.349-387. https://doi.org/10.1002/9781118156247.ch20

WALIA, K.; ARGÜELLO, H.; LYNCH, H.; GRANT, J.; LEONARD, F.C.; LAWLOR, P.G.; GARDINER, G.E.; DUFFY, G. The efficacy of different cleaning and disinfection procedures to reduce Salmonella and Enterobacteriaceae in the lairage environment of a pig abattoir. International Journal of Food Microbiology, Grugliasco, v.246, p.64-71, 2017. https://doi.org/10.1016/j.ijfoodmicro.2017.02.002

ZHANG, C.; CUI, F.; ZENG, G.-m.; JIANG, M.; YANG, Z.-Z.; YU, Z.-g.; ZHU, M.-y.; SHEN, L.-q. Quaternary ammonium compounds (QACs): A review on occurrence, fate and toxicity in the environment. Science of The Total Environment, Barcelona, v.518-519, p.352-362, 2015. https://doi.org/10.1016/j.scitotenv.2015.03.007 